\title{
23 Research Soure \\ Effects of the COVID-19 outbreak on the use and \\ perceptions of metropolitan agricultural parks. Evidence from Milan and Naples
}

\author{
Valentina Cattivelli \\ UniNettunoUniversity \\ Vincenzo Rusciano \\ Università degli Studi di Napoli Parthenope \\ Andrea Gatto ( $\square$ a.gatto@greenwich.ac.uk) \\ Wenzhou-Kean University
}

\section{Case Report}

Keywords: Milan, Naples, COVID-19, metropolitan agricultural parks, MAP, governance, urban regeneration, qualitative methods

Posted Date: January 20th, 2022

DOl: https://doi.org/10.21203/rs.3.rs-1257486/v1

License: (a) (1) This work is licensed under a Creative Commons Attribution 4.0 International License. Read Full License 


\section{Abstract}

This article describes the multi-function of the metropolitan agricultural parks in Milan (Parco Agricolo Sud Milano) and Naples (Parco De Filippo), as well as their resilience within the last period of the lockdown enforced for limiting the COVID-19 diffusion in Italy. These parks play an important role in the urban regeneration and social inclusion processes in their relative metropolitan areas. Nevertheless, the restrictions imposed to limit COVID-19 contagions have imposed their closure or severely limited their activities, with evident consequences on the local population wellbeing. Exploiting a document analysis and the elaboration of a semi-structured interview with the directors, the article lists the multiple functions of the parks and underlines their multidimensional governance vocations for fostering sustainable development (environmental, economic and social functions). The study also reveals that, during the lockdown, the parks' activities have been strongly reduced or restructured. Recreational and educational activities were lifted in Parco Agricolo Sud in Milan, whilst local farms restructured their food supply, fostered their network and linkages with the urban distribution channels. In the same period, the metropolitan park analyzed in Naples had to stop its activities and reorganize into smart-working, holding meetings with its users throughout dedicated apps. Lastly, the article reveals that economic activities were resumed with greater urgency in Milan, whereas in Naples the recovery of the social ones has taken on greater importance. Farms network continued to operate in Milan Metropolitan Parks. Despite the limited number of offered social initiatives here, the local population was attracted. Right after the post-lockdown phase, the De Filippo urban park has, indeed, resumed all social activities: care of community gardens, public events, school visits.

JEL codes: 013; 018; Q01; Q23.

\section{Introduction}

Metropolitan parks (MPs) represent a crucial element in the urban fabric, as they are able to enhance the environmental quality of the spaces and the social conditions of local communities [1,2]. Recent observations have revealed their positive role in promoting the quality of life for urbanites and their health $[3,4]$. Being essential parts of the local ecosystem, vegetation, water bodies and green spaces herein located act as buffers against congestion, noise, and pollution [5,6]. They support the city's green infrastructure and provide multiple ecosystem services, above all providing and regulating services and cultural services [47]. Beyond these effects, the provision of cooling and shade accelerate recovery from heat and urban heat islands, improving further environmental conditions $[7,8,27]$.

Other studies emphasize MPs' social functions. Metropolitan parks appear to facilitate physical activity and social interactions, which in turn promote the mental health of users [9]. Being a green space, they provide a refuge from an increasingly stressful life [44], promote social cohesion [45], enhance personals' wellbeing [46]. They also serve as a valuable tool to ensure greater food security, to combat environmental degradation and speculation [10,].

As commons, urban green is crucial to facilitate environmental protection, social wellbeing and economic growth, being instrumental to citizenship reactivation and cities resilience [28,29,30,31.32, 50, 51].

However, the magnitude of these effects depends on some dimensions, like quality and accessibility [11], and on the societal pressure for the conversion into urban areas [12]. 
Similar effects have not been tested for Metropolitan Agricultural Parks (MAPs). These parks represent areas in which agricultural activities are created, rediscovered or strengthened in order to safeguard and protect the territory and the metropolitan environment [13]. MAPs are, in fact, the result of rural areas urbanization in proximity of urban centers. They are often located nearby settlements forms where the edge between urban and rural spaces goes to fade and the legacy of the rural society and the agricultural landscape is often eroded $[33,34,35]$. Their role appears fundamental in providing some "commons" - such as urban ecosystem and urbanrural landscape quality and goods, facilities and amenities for the urban people. In this sense, they may be considered as such as short foods supply chain, recreational, tourist, social and cultural services. MAPs can be a powerful tool to get citizens involved in the participation of community's activities, in a renovated local development and citizens participation pattern [43]. However, most scholars focus on the study of urban-rural patterns and functions and support local administrations on the planning agenda drafting, less on the multifunctional and integrated characteristics analysis, as well as on the environmental, social and economic values of these parks (see [35,36]).

Nevertheless, planning MAPs also appears today to carry noteworthy criticalities. Problems can be generally traced back to two fundamental aspects: the study of management costs and the monetary quantification of the possible benefits of green areas within urban contexts [14]. With the COVID-19 emergency, a third aspect has been created - the one related to the usability of these areas considering the restrictions to protect the health of citizens. Research on how pandemics change the activities of MAPs and their adaptations to the restrictions is of great interest and not frequent at the moment.

To limit the COVID-19 diffusion, the national and regional authorities have imposed social distancing measures and stay-at-home orders, including a ban on free movement except for the case of urgent needs (viz. lockdown, March-May 2020). These restrictions have strongly limited the social, environmental and economic activities including MAPs enjoyment $[37,38]$. Amongst the others, the cultivation of agricultural areas has been limited or suspended due to lack of personnel whereas the access to farmhouses, urban gardens or other recreational activities has been interrupted [22]. However, during the outbreak, some Italian metropolises have adopted measures to preserve green and agricultural spaces, safeguard users health as well as the continuity of economic activities located there. This also happened in Parco Agricolo Sud Milano in Milan Metropolitan area and De Filippo Park in Naples metropolitan area.

Parco Agricolo Sud Milano, amongst the first in Europe in terms of extension, has resisted the pressures for its conversion to become residential and productive space. On top of that, it has been suffering from management difficulties due to its extension throughout 61 municipalities in Lombardy. Multiple actors exist here, which make the local food chain dense and articulated (namely, community gardens, farms, vegetable growers, GAS, agritourism, recreational and education activities etc.). During the lockdown, their activities have stopped, except for some farms that have reorganized to sell their products online or to get the land prepared for spring and summer crops. The urban gardens and farmhouses have been closed to the public. "Mercati della Terra" (Earth Market, @Slow Food) and the recreational and educational activities have been, thus, cancelled.

The management of public green areas in Naples metropolitan area focuses on the redevelopment of abandoned spaces policies. The creation of the gardens in the De Filippo urban park, the third-largest park lying within Naples, is part of this objective of the redevelopment of the public areas. It also includes the promotion of local products [52] and the knowledge of cultivation techniques with cultural exchanges and reintegration policies 
related to highly influential social and ecological factors [53] This objective is achieved with the collaboration of all stakeholders. Local governments and proactive citizenship can encourage such practices with low social costs compared to the advantages in environmental, social and reputational terms. During the lockdown, this park had to stop its activities and reorganize them. Thanks to smart working, it has continued in supporting urban gardens users with additional/substitutive therapy for diseases such as drug use and ludopathy; it has also held meetings to organize subsequent events with the many associations, schools and city committees making use of apps.

The purpuse of this study is to explore, in a comparative perspective, the ways in which MAPs react and change their activities due to the restrictions imposed by the containment of the COVID-19.

The decision to focus on these metropolises is motivated by several reasons. Milan and Naples are among the few Italian metropolitan areas to have a MAP and consequently to have experienced the environmental, social and economic effects of their presence. The choice also depends on what happened during the lockdown (MarchMay 2020). During this period, Milan and Naples had been the two most affected metropolitan areas by this pandemic in terms of infection figures. Therefore, these metropolises applied strong restrictions on economic and social activities, including those that limited MAP activities and accessibility. Moreover, with only a few exceptions, the multidimensional functions of both parks, the implications of the restrictions in their functionality and their resilience against the lockdown effects have rarely been analyzed in prior studies.

This paper seeks to fill this gap in knowledge by listing the functions of these parks, as well as their probable changes and resilience due to the restrictions induced by COVID-19 diffusion.

As such, it is structured as follows. The second section provides details on the undertaken research method. The third section highlight the case studies profiles the functions of Parco Agricolo Sud Milano and De Filippo parks. The fourth section outlines the diffusion and impact of COVID-19 in the two metropolitan areas. Details the possible implications of COVID-19 on the functionality of these parks and selected solutions adopted to mitigate the negative effects of the lockdown restrictions are depicted. This analysis was carried out amidst the lockdown period (March-May 2020), and the following period (June-October 2020). The last section (five) discusses and concludes the study.

\section{Methods}

The findings of this paper concern the functions of the two considered metropolitan agricultural parks, as well as their resilience during and after lockdown.

The first point is described at the end of a document analysis that covered spatial regulations and plans (Table 1), as well as internet websites. 
Table 1

List of laws, plans and websites considered

\begin{tabular}{|lll|}
\hline Parks & $\begin{array}{l}\text { Type of } \\
\text { document }\end{array}$ & Document \\
\hline $\begin{array}{l}\text { Parco } \\
\text { Agricolo } \\
\text { sud } \\
\text { Milano }\end{array}$ & $\begin{array}{l}\text { Regional } \\
\text { law } \\
\text { n.86/93 }\end{array}$ & Piano generale delle aree regionali protette \\
& $\begin{array}{l}\text { Regional } \\
\text { plans } \\
\text { adopted } \\
\text { with DGR } \\
7 / 818 \text { del } \\
\text { 2000 }\end{array}$ & Piano Territoriale di Coordinamento del Parco Agricolo Sud Milano \\
& $\begin{array}{l}\text { Regional } \\
\text { plan } \\
\text { adopted } \\
\text { with Park } \\
\text { delibera } \\
\text { n. } \\
33 / 2007\end{array}$ & Piano di settore agricolo \\
& Website & www.cittametropolitana.mi.it/parco_agricolo_sud_milano \\
\hline $\begin{array}{l}\text { De } \\
\text { Filippo } \\
\text { Park }\end{array}$ & Website & https://www.eracoop.it/index.php/servizi/dipendenze/item/39-lillipu-centro \\
\hline Source: authors' elaboration, 2021 \\
\hline
\end{tabular}

The resilience of these parks is evaluated after the processing of semi-structured interviews submitted to the staff in charge of the Environmental valorization department at Parco Agricolo Sud Milano, the coordinator of Lilliput association for De Filippo park of Naples, as well as to the members of WWF Naples in mid-October, 2020.

The questions aim at collecting information related to the COVID-19 emergency and its management, the reactions of all actors operating in these parks and the adopted solutions to mitigate the negative effects of closure restrictions during the lockdown (March-May, 2020). They also refer to the initiatives realized after the lockdown in the period June-October, 2020. The answers were processed by text analysis and reported in this article.

\section{Case Studies}

\subsection{Parco Agricolo Sud Milano: a park, many vocations}

The Parco Agricolo Sud Milano is one of the oldest agricultural parks in Italy. It was formally established with the Lombardy Region law n. 24 of 1990. However, its presence and diffusion in the urban and peri-urban territory of the province of Milan began some decades before. Today, it includes the agricultural and forest areas of 61 municipalities and extends for 47 thousand hectares - as sketched in figure 1 and figure 2 .

The regional law classifies the park as an agricultural park and metropolitan belt. This classification depends on its geographical position, which is close to a large metropolis, the Milanese one, in a densely urbanized context. 
The park presents all the typical features of peri-urban spaces (scattered human settlements, comprehensiveness residential/productive functions, marginal and interstitial agriculture etc.) and connects local natural areas into the agricultural system [48]. For its geographical location, it denotes a natural east-west ecological corridor, between Ticino and Adda river catchments. Although interrupted by residential and productive settlements, scattered over the territory, this complex rural and natural landscape system supports the pressures for its conversion into residential places. A network of groundwater and surface water, native and cultivated plant species coexist with farmsteads, castles and abbeys of great artistic and cultural value, as well as residential and productive settlements (ibid.).

The park has a strong agro-sylvo-cultural vocation and it aims at promoting "the protection and recovery of the landscape and the environment of the areas connecting the city and the countryside, as well as the connection of external areas with the urban green systems, the ecological balance of the metropolitan area, the protection, qualification and strengthening of agro-sylvo-cultural activities in line with the destination of the area, the use of cultivation and recreation of the environment by citizens" (as reported in the park's constitutive act).

Agricultural activities that are practiced are conducted professionally and for social purposes, but also for touristrecreational and environmental reasons by about 900 farms. Those are sparsely located all along with the park territory. They are specialized in the production of arable crops (more than 30,000 hectares, i.e., $87 \%$ of the agricultural area of the park). Woody crops (fruit trees and vines) have marginal importance. Similarly, permanent meadows have a reduced extension, while in the past they were the main source of food production for cattle. Today, more productive forage crops have been produced. These are better suited to sustain the high milk production of modern dairy cattle. Farms protect all these crops for their economic value; however, particular attention is paid to the marcite, which represents a typical crop of the lower Milanese area and is therefore also important from a historical point of view.

Farms also offer experiences of rural tourism (such as farm visits, typical products tasting, etc.). 79 of them are associated with an informal network which is mapped in figure 2. This map is available on the park website. Evidencing distance among farms and verifying what kind of services farms offer helps designing recreational routes and farm visits. It can also facilitate reorganizing the distribution of agricultural products in the nearby city markets in a more efficient, economic way, with a lower environmental impact.

In this park, 24 GASs (Gruppo di Acquisto Solidale, solidarity purchasing groups) and some farmers' markets operate. The first "Mercato della Terra" - Slow Food Italy is also there. Their presence is a signal of the strong focus on environmental protection, and the attention on supporting homegrown agricultural productions. They also represent a valid source of food for Milan metropolitan area.

The Park has the highest number of urban gardens in the whole Lombardy Region [47]. Almost all the municipalities operating here have started urban gardening projects for the integration of vulnerable categories (including, above all, the elderly and low-income people) through the cultivation of small plots of land. Through their concession for a limited period, the municipalities aim to preserve the surrounding environment, reduce the impact of human activities and beautify the whole park area.

This park also offers educational activities (visits, projects) at natural and agricultural areas and directly at farms. Some of these activities are directly addressed to the schools. Finally, it organizes leisure activities for the visitors which can be experienced both on foot and by bicycle. 
By carrying out all these activities, the park assumes social, economic and environmental functions, endeavoring the promotion of sustainable development assets. This is confirmed by the interviewed park's officer.

"The park is a sort of barrier to the conversion of agricultural land into residential and productive areas. The suspension of economic activities due to COVID-19 has partly slowed down the demand for conversion. The park serves to mitigate the pollution of this area which is among the most productive and populous in Italy".

Park's officer, authors' interviews, October 2020

In addition to the offsetting and mitigation effects on the climate and the use of natural resources, the director dwells on the effect that the attendance of the park has on the quality of life,

"The park is frequented by school children and families. The former learn to recognize plants through educational ecology paths. Families also participate in workshops on farms and spend time together. All these activities help to cement the social relationships between pupils and families. In addition, spending free time in nature has positive effects on health and mood".

Park's officer, authors' interviews, October 2020

Beyond environmental and social effects, the director includes food-related issues into the park's contributions:

"Thanks to the courses given on environmental and agri-food topics, provided to students and adults, the awareness of the importance of the environment increases. Participants learn the rhythms of nature and appreciate it. They also understand where food comes from and therefore become more aware consumers. This is also noticeable among those who cultivate the many urban gardens in our territory".

Park's officer, authors' interviews, October 2020

The park's governance is structured as follows. Beyond the administrative structure, there is a political management organism that is made up of the president and 10 directors representing the entities that are somehow involved in the park management. Other organs are: the mayors' council, constituted by the mayors of the municipalities located into the Park; the assembly, which formulates opinions on the park's regulation and planning documents and reflects the interests, tensions and ideas of all 61 municipalities; the agricultural technical committee, which is specifically set up to examine and offer technical support to all interventions concerning the exercise of agricultural activity; the Commission for the Landscape, which operates on the procedures for the issuance of landscape authorizations and landscape compatibility assessments; and Associazione per il Parco Sud Milano Onlus, which operates in the park for the local agriculture, culture and values promotion.

GAS, farmers' markets and farms actively adhere to the initiatives provided by the Solidarity Economy District of Parco Agricolo Sud Milano (DESR). The latter is active since 2008, thanks to the initiative of various actors of the Milanese Solidarity Economy, environmental associations and local institutions, with the aim to preserve and requalify the park and its agriculture. The basic assumption that moves the path of DESR is that it is possible to safeguard the vocation of the park with initiatives to defend the farmsteads and their income as well as against the consumption of land: qualifying supply and demand, encouraging direct sales and 'internal' cycles of product processing, supporting multifunctionality (but without overwhelming agricultural activity), promoting 
agrobiodiversity capable of affecting the monocultures of the Park (rice and cereals) and intensive cattle breeding.

The park's officer was also asked about the park's governance.

"The presence of many actors is positive because in this way there are many points of view and interests. However, it makes it difficult to make decisions".

\subsection{De Filippo park, Naples - between territory recovery and the creation of participatory governance}

52 parks compose the urban greenery of Naples metropolitan. Among these parks, De Filippo Park in Ponticelli emerges for its multifunctional vocation. This park is located in the eastern part of the Neapolitan metropolitan area and is part of the VI Municipality of Naples along with Barra and San Giovanni a Teduccio (Figure 3).

The park was built between the late 80s and early 90s and opened in 1995. Now, it occupies an area of 12 hectares of which one hectare is currently under cultivation. Due to vandalism, the park was closed in 2008 and reopened only in 2015, and part of the park has been assigned to the Lilliput association for the realization of an urban gardening project. The park has a morphologically flat structure in the southwest part, while in the northeast part there are artificial hills. There are numerous access routes and playgrounds for children, rest areas and a pedestrian path of about $1.5 \mathrm{~km}$ that surrounds the entire space. At the edge of the gardens, there is an artificial hillock of 4 hectares now in a state of abandonment and waiting to be assigned by protocol.

Inside De Filippo park, there is a set of urban gardens. With a 2015 memorandum of understanding, the City of Naples, has entrusted these spaces to the Department of Drug Addiction of A.S.L. (local health center) Napoli 1 with the daycare center Lilliput.

The creation of gardens in De Filippo park is part of a 2011 project to redevelop the public area, "a color park", promoted by the Le Kassandre association and a master's degree in participatory planning and community mediation organised by Fondazione Mediterraneo. The purpose of the redevelopment was to render these spaces available to the community for commercial and cultural activities, obviously encouraging cultural exchanges and integration. Preventive analyses were carried out by the order of agricultural experts of Naples who certified the healthiness of the land suitable for the cultivation of vegetables and not only for ornamental plants.

The main idea is to create an area dedicated not only to users, but also to other families, associations and citizens, to make them aware of the protection and care of their neighborhood. The mission of the park is to ensure a green space to create territorial culture. People have the opportunity to take custody of a small plot of land with members of schools, associations, city committees, churches and archaeological organizations that the Lilliput, among others, has formed within a social network. Through agriculture, they can learn a job, thus beginning a process of reintegration into work and society starting from the appropriation of important public spaces.

Lilliput has tried to create a network for the management of the various plots that make up the urban gardens. Some of the park's terraces have been assigned by Lilliput to other associations (Libera, Emergency, etc.), groups or institutions, as well as primary schools. This is a fine example of aggregation that involves not only the children belonging to the associations but also the people of the neighborhood. 
Initially, the few park's terraces were entrusted only to people involved in rehabilitation pathways for the treatment of various addictions, such as alcohol and drugs. Later, the garden was opened to schools, associations and citizens of the metropolitan area: today there are 141 cultivable plots. Each area of the garden is assigned to different associations or institutes and identified with different colors (Table 2). Given the large number of gardeners operating there, meetings are managed by a city committee and are divided by area.

In the end, the project involved associations, individual citizens, including foreigners, committees and religious representatives.

Table 2

Actors interacting for the management of De Filippo park, in Ponticelli

(source: our elaboration).

\begin{tabular}{|lll|}
\hline Institutional representatives & Social representatives & $\begin{array}{c}\text { Citizen } \\
\text { representatives }\end{array}$ \\
\hline The municipality of Naples & Santi Pietro e Paolo Church, Ponticelli & $\begin{array}{l}\text { Citizen } \\
\text { Committee }\end{array}$ \\
\hline Naples Municipality Environment Department & $\begin{array}{l}\text { S.mo Rosario Maria delle Grazie del } \\
\text { Felaco Church, Ponticelli }\end{array}$ \\
\hline President of 6th Municipality of Naples & Emergency \\
\hline U.O.C. Director (belonging to ASL NA1) & Libera \\
\hline Lilliput Day Center ASL NA1 DSB 32 & "Arteteca” cultural association \\
\hline $\begin{array}{l}\text { College of Agricultural Experts and Graduated } \\
\text { Agricultural Experts }\end{array}$ & “Pax Cultura” cultural association \\
\hline Archimedes Scholastic Institute & ReMida Social Promotion Association \\
\hline Calamandrei Scholastic Institute & Arcobaleno cultural association \\
\hline Sannino/Petriccione Scholastic Institute & Ardea cultural association \\
\hline Mother Claudia Russo Institute & \\
\hline
\end{tabular}

\section{Impact And Resilience Of The Maps Over The Covid-19 Outbreak 4.1 The COVID-19 diffusion and impact in Milan and Naples}

On February 21, 2020, the first cases of people who tested positive for COVID-19 were recorded in Italy, triggering the whole of Europe and the world.

From 'day zero' on, a series of data relating to the spread of the epidemic, both nationally and locally, are regularly monitored by the Civil Protection. Italy has been one of the most severely affected worldwide countries and has enforced some of the harshest restriction policies in the world, COVID-19 spread has immediately posed notable economic, social and environmental problems [37,39,40].

The first death due to the COVID-19 infection was observed on Feb 21, 2020, and in mid-March, 2020, the number of deaths rapidly increased, resulting in almost 50\% of excess deaths from any causes in March 2020. In April 2020, excess mortality was still 36\%. In the first 2 weeks of May 2020, excess mortality decreased to 3\%, and in 
the last 2 weeks of May 2020, the number of deaths was lower than that observed in the previous years (-7\%) [23] (Figure 4).

Overall, about 44,000 excess deaths have been registered in the 3-month period considered, as compared with 33,386 officially registered by the Civil Protection Department as COVID-19-related. [23]. The difference is largely due to the under-certification of COVID-19, mainly in March, but some of these excess deaths are likely to have occurred owing to inadequate management of other diseases during the COVID-19 pandemic and hence to excess mortality from elective procedures or other causes [41].

Several studies have tried to motivate the fact that Italy was the first and most affected country in Europe by the outbreak [42]. According to [18], the high level of similarity in terms of economic, geographical, climatic and environmental conditions between the most affected area in China (Wuhan) with the most Italian one (Po Valley) is a possible explanation. Specifically, possible evidence relating COVID-19 cases and Nitrogen-related pollutants and land take arise, particularly in the Po Valley area as well as in Wuhan area. Other studies were conducted to understand a possible correlation between the number of infections and the different rural landscapes of the country. According to [19], that areas with more highly diversified agriculture, valuable landscape, more forests and protected areas have on average fewer cases of contagion (mean 10\%) than more energy-intensive landscapes.

Within urban ecosystems, a wealth of studies provided evidence regarding the benefit of urban agriculture and urban garden to public health. [20] have shown the benefit of Edible Green Infrastructure (EGI) in terms of urban regeneration and wellbeing, suggesting a global rethinking of food security and food supply chains pursuant to the recent developments from the COVID-19 outbreak. As per [21] community urban gardens can help on supporting community resilience in terms of disasters and pandemics. [22] emphasize their role, as an example of social innovation, to support self-organized initiatives for food provisioning (and thus for food accessibility) at the time of personal and mobility restrictions due to COVID-19 to be considered amongst a wider innovationoriented approach to COVID-19 solutions [54].

In October 2020, an increase was confirmed in the new cases reported in Italy for the ninth consecutive week with a cumulative incidence. In the period 14/9-27/9, 34.2 per 100,000 inhabitants were affected by COVID-19. A steep increase with the median age of the cases of 42 years vs 41 the previous week was registered (Figure 5).

Campania and Lombardy were amongst the most affected Italian regions during the second COVID-19 contagions wave with more than 400 infected per day each (Figures 6-7)

Furthermore, unlike the first wave, during the second wave, even the metropolitan cities of Milan and Naples are strongly affected. The trends are comments in Figure 6 and Figure 7.

\subsection{Resilience of the two MAPs during and after the lockdown}

Parco Agricolo Sud Milano closed on 8 March 2020, as an enforcement of the Prime Minister Decree of the same day, which ordered the lockdown and termination of all non-essential productive, including those recreational and educational ones.

During the lockdown, all park activities were stopped according to this national legislation. Recreational and educational activities in the program were cancelled, while the farmhouses began to no longer receive guests. The 
farms continued to prepare the land and cultivate it, albeit with difficulty. Those included in the network mentioned before reorganizing their commercial structure, in order to continue to sell their products. They improved their online sales systems and restructured their logistic channels to reduce movements for the goods delivery. According to the interviewee, this reorganization was quite successful, so much so as to mitigate the losses resulting from the inability to continue with the hospitality and educational activities. Even the gardens were closed and no longer cultivated though this decision was taken by the municipalities of the park as responsible for their management. The Earth Market and farmers' markets were no longer organized. During that period, many actors were no longer active in the management of the park. In fact, the 61 municipalities were involved in the emergency management, while the administrative bodies of the park worked to assist all the other actors operating there, monitoring the situation and evaluating possible solutions to mitigate the negative effects on the activities.

In the southern area of the Milan municipality included in the park, the QuBi project has been strengthened. Initially intended only to provide assistance in the daily shopping of some families in difficulty, during the lockdown the project has seen its beneficiaries grow exponentially due to the increase in the number of households without work or in difficulty in paying bills. Part of the food collected from farms in the Park and from local supermarkets and shopkeepers was stored at the premises of some voluntary associations, parishes and listening centres.

The activities of the park were resumed in May 2020, in compliance with the directives for the containment of contagion. At first, the park organized virtual tours and the Food Film Festival, totally online. On the park website, people could visit park areas virtually and attend the screening of films realized by independent and food-themed filmmakers and uploaded to this platform.

Afterwards, three of its areas were reopened to visits in attendance, which were attended by a fair amount of people. The turnout was considered as a sign of confidence in the park and a desire to return to it after the closing. The Earth Market was again organized, but the reorganization of the stands strictly followed the requirements for social distancing. Only 25 farms were able to participate (compared to the 40-50 that normally took part before). Meantime, online sales continued. Urban gardens also reopen. Recreational and educational activities in support of schools were not immediately resumed, due to the difficulties of some schools to resume lessons to comply with the anti-contagion provisions.

The lockdown period led to the closure of the parks in the city of Naples from March to May 2020. That period required different management of the activities related to De Filippo park by its users. Given the impossibility of using the fields due to the mobility restrictions, the urban gardeners continued to confront each other only through WhatsApp meetings. ASL Napoli 1 patients, who were used to cultivating the plots before the COVID-19 outbreak have continued these activities via smart working. Thanks to a resolution, they were able to return to the gardening activities from April 28. According to Lilliput head, the situation to be managed was very complicated from various standpoints.

From a social point of view, many users had suffered a regression due to the impossibility to follow outdoor activities such as the garden and with the forced obligation to stay at home the risk of falling back into illegal activities such as gambling and drugs was high. From an environmental point of view, the cultivated fields suffered the loss of the entire harvest and the need for considerable efforts to restore them. Initially, the access to the fields was managed on shifts and in small groups. Moreover, the common areas were closed to avoid the risk 
of people gathering. From the point of view of security, the gardeners complained about the difficulty of controlling the park through cameras and surveillance, even more important in this pandemic period.

Since the beginning of May, all the other users of the garden of the De Filippo park have also reused their spaces. The schools have returned to take guided tours of the park and others have applied to have a space to cultivate their own.

The park eventually resumed organizing events. On 4 October 2020, there was the first major meeting in De Filippo park organized with WWF Naples. The event had as background the social garden realized in De Filippo municipal park by the Lilliput daycare center of the Asl Napoli1 center - coordinated by Anna Ascione - and by the community of gardeners, gathered in a civic committee.

WWF Naples wanted to reward the reality of Ponticelli for the experience of revalorization of greenery and social and urban spaces. Symbolically, it was donated a tree planted in the garden area where several specimens have been stolen and damaged during the outbreak. Citizens and associations of eastern Naples have also offered their contribution to the purchase of other trees that will be planted later, creating an orchard in an area of the urban park still to be recovered. According to Ornella Capezzuto, president of WWF Napoli, this park is characterized by its social value and it is also recognized as a high naturalistic value for the number of bird species. A small specimen of a hawk was found inside the park and it has been taken care of with the Legambiente Association.

The various activities of this park are shown to be able to obtain an effective regeneration of the territory. This is only possible through the meeting of the needs of different actors: the municipal administration, the horticulturists and intermediaries [25]. Figure 8 portrays a speech held during the WWF meeting.

\section{Discussion And Conclusion}

This article described the multiple functions of the metropolitan agricultural parks (MAPs) in Milan and Naples. The paper also investigated the MAPs resilience focusing on the end of the second lockdown, applied for limiting COVID-19 diffusion in Italy.

Both parks contribute to improving the environmental quality of the spaces and the social conditions of local communities, as perceived by their officers. Pressure on natural resources and for land conversion in residential settlement result to have shrunk in their territory. Social interactions among users appear to stimulate the users. This happened thanks to the offer of numerous cultural, educational, and social activities involving civil society inter alia, students, companies and voluntary associations. Beyond social isolation and environmental degradation, both parks prevent food insecurity in the local population. In their territories, many farms operate and sell their products to visitors, local markets and distribution centers. Thanks to the courses given on environmental and agri-food topics to students and adults, the awareness of the importance of the environment increases. Participants learn the rhythms of nature and appreciate it. They also understand where food comes from and therefore become more aware consumers. This is also noticeable among those who cultivate the many urban gardens in both territories. As such, parks role in providing public goods, like urban ecosystem and urbanrural landscape quality, as such as short foods supply chain, recreational, social and cultural services is evident. 
With the COVID-19 emergency, both parks had to reconsider their entire organization and the extent of all activities previously offered due to the restrictions imposed to protect the population's health.

These restrictions have strongly limited the MAPs activities: the cultivation of agricultural areas has been limited or suspended due to lack of personnel, and the access to farmhouses or other recreational activities was interrupted. The educational and recreational activities were stopped and the urban gardens closed to the public. The functionality of the parks was, therefore, reset to zero. This was justified by the high number of infections that were recorded in both the metropolitan areas.

However, during the lockdown, new activities were experienced. In Milan, the farms that had joined a network within the park reorganized their production and distribution. They tried, through the network, to reorganize the logistics of shipments and get their products also in the nearby urban municipalities. The reorganization of the other activities has not been possible because of the destinies. The didactic activities were not realized because of the closure of the schools; the company visits were not even held for the prohibition to move for non-essential reasons. The reorganization was also difficult because of the high number of actors present in the Milanese park (in addition to the 61 municipalities, also voluntary organizations and associations).

The management of MAPs is a concerted matter. Their extension over vast territories that go beyond traditional administrative boundaries impose systems of multistakeholder governance targeting a multitude of actors.

Within their design, particular attention is paid to the allocation of responsibilities and competencies. This is done through regulatory acts or concerted projects and, above all, the participation of a plurality of public and private stakeholders who, in concert, are called upon to work to promote the proper management of parks. This applies to both Milan and Naples.

Milan MAP has determined with special regulations the relationships between the participating municipalities as well as the promotion of relationships between the various actors through the implementation of projects such as the networking of small producers or municipalities for the realization of social gardening experiences. This activity is also favored by the "aggregating" action of the GAS and the Rural District. In any case, all these efforts for the convergence of the various interests lead to a diversity of intentions that reflects the multifunctional (tourist, agricultural, social and environmental) vocation of the park itself. This happens regularly under normal conditions. During the lockdown, however, there have been problems due to the commitment of many actors, the municipalities first and foremost, in the management of the emergency.

At the end of the lockdown, activities were resumed very slowly. The agricultural activities continued, while the visits and lessons were mainly offered in online mode. Difficulties in the reopening of schools and restrictions on excursions discouraged scheduling in the very short period of recreational and educational activities.

The analysis of the case study relating to the Ponticelli urban park reveals management focused on the redevelopment of the territory, understood as the recovery of abandoned spaces, social inclusion and enhancement of the territory.

The urban gardening project is well organized and tries to overcome the difficulties of meeting the needs of the various local actors characterized by different targets and socioeconomic conditions. The relationship with the public administration, even if positive, is often fragmented and is mediated by the lead partner (Lilliput daycare). 
Unfortunately, there was no lack of acts of vandalism within the structure which undermined the project effectiveness.

These activities feed what is defined as social innovation in the urban sphere [26] creating the possibility of determining urban change from below by participating in the birth and expansion of these activities seeing the urban park as a multifunctional public space.

Much remains to be done in the municipal park De Filippo of Ponticelli. A good part of the public structure, in fact, has been closed for several years due to lack of maintenance and is also excluded from the redevelopment works that the city administration has planned for the next few years. In addition, both the area used for dog walking and the area equipped with carousels for children remain closed to date. WWF activists are carrying out a monitoring of the 52 urban parks in the municipality of Naples to update the one previously carried out in 2008. The monitoring of the first fourteen parks, including De Filippo park, shows a worsening of the general conditions. The most critical points concern the care and quality of the greenery and the inaccessibility of some parks still closed before the lockdown of March 2020 due to the lack of staff. Moreover, the approval of a municipal regulation for urban green areas is of fundamental importance.

This paper reported two case studies. It can be instructive for the single evidence though does not have the goal to draw generally-applicable rules. Next studies could extend the number of respondents to other park operators or include an analysis of the resumption of activity at a greater distance from the end of the lockdown. Among the interviewees, gardeners, farms and tour operators could be included, as well as the public administrations that operate there.

\section{Declarations}

\section{Data availability}

The datasets generated during and/or analysed during the current study are available from the corresponding author on reasonable request.

\section{Informed consent}

- Informed consent was obtained from all individual participants included in the study.

- Verbal informed consent was obtained prior to the interview.

\section{References}

1. Kim, H., Lee, G., Lee, J., \& Choi, Y. (2019). Kim, H. S., Lee, G. Understanding the local impact of urban park plans and park typology on housing price: A case study of the Busan metropolitan region, Korea. Landscape and Urban Planning, 184, 1-11.

2. Wang, Q., \& Lan, Z. (2019). Park green spaces, public health and social inequalities: Understanding the interrelationships for policy implications. Land Use Policy, 83, 66-74.

3. Su, S., Zhang, Q., Pi, J., Wan, C., \& Weng, M. (2016). Public health in linkage to land use: theoretical framework, empirical evidence, and critical implications for reconnecting health promotion to land use policy. Land use policy, 57, 605-617. 
4. Gascon, M., Triguero-Mas, M., Martínez, D., Dadvand, P., Rojas-Rueda, D., Plasència, A., \& Nieuwenhuijsen, M. (2016). Residential green spaces and mortality: A systematic review. Environment International, 86, 60-67.

5. Escobedo, F., Kroeger, T., \& Wagner, J. (2011). Urban forests and pollution mitigation: Analyzing ecosystem services and disservices. Environmental Pollution, 159, 2078-2087.

6. Gómez-Baggethun, E., \& Barton, D. (2013). Classifying and valuing ecosystem services for urban planning. Ecological economics, 86, 235-245.

7. Grahn, P., \& Stigsdotter, U. (2010). The relation between perceived sensory dimensions of urban green space and stress restoration. Landscape and urban planning, 94(3-4), 264-275.

8. Aram, F., Solgi, E., Baghaee, S., García, E., Mosavi, A., \& Band, S. (2020). How Parks Provide Thermal Comfort Perception in the Metropolitan Cores; A Case Study in Madrid Mediterranean Climatic Zone. Climate Risk Management, p.100245., p.100245.

9. Akpinar, A. (2016). How is quality of urban green spaces associated with physical activity and health? Urban Forestry \& Urban Greening, 16, 76-83.

10. Ghose, R., \& Pettygrove, M. (2014). Actors and networks in urban community garden development. Geoforum, 93-103.

11. Markevych, I., Tiesler, C.M., Fuertes, E., Romanos, M., Dadvand, P., Nieuwenhuijsen, M.J., Berdel, D., Koletzko, S. and Heinrich, J., 2014. Access to urban green spaces and behavioural problems in children: Results from the GINIplus and LISAplus studies.. Environment international 71, 29-35.

12. Chun, J., Kim, C., Kang, W., Park, H., Kim, G., \& Lee, W. (2019). Chun, J., Kim, C. K., Kang, W., ParkSustainable Management of Carbon Sequestration Service in Areas with High Development Pressure: Considering Land Use Changes and Carbon Costs. Sustainability, 11(18), 5116.

13. Comune di Casalecchio. (2020). Regolamento sulla pianificazione territoriale. Casalecchio: Comune di Casalecchio.

14. Gatto, P. (1988). La valutazione del paesaggio forestale e del verde urbano.. Monti e Boschi l, 28-34.

15. Citta' Metropolitana di Milano. (2017). Guida Aziende Agricole del Parco Agricolo Sud MIlano. Milano: Citta' .

16. Citta' Metropolitana Milano. (2020). Citta' Metropolitana Milano, website. Retrieved from

17. Orto Sociale Ponticelli. (2020). Orto Sociale Ponticelli, website. Retrieved from

18. Murgante, B., Borruso, G., Balletto, G., Castiglia, P., \& Dettori, M. (2020). Perchè prima I'Italia? Aspetti medici, geografici e pianificatori del Covid-19. GEOmedia, 23(1).

19. Agnoletti, M., Manganelli, S., \& Piras, F. (2020). Covid-19 and rural landscape: The case of Italy. Landscape and Urban Planning, 204, 103955.

20. Russo, A., \& Cirella, G. (2020). Edible Green Infrastructure for Urban Regeneration and Food Security: Case Studies from the Campania Region. Agriculture 2020, 10, 358.

21. Shimpo, N., Wesener, A., \& McWilliam, W. (2019). How community gardens may contribute to community resilience following an earthquake. Urban For. Urban Green. 2019, 38, 124-132.

22. Cattivelli, V., \& Rusciano, V. (2020). Social Innovation and Food Provisioning during Covid-19: The Case of Urban-Rural Initiatives in the Province of Naples. Sustainability, 12(11), 4444.

23. GIMBE. (2020, October 3). Retrieved from GIMBE: https://coronavirus.gimbe.org/

24. Sole24Ore. (2020, October 10). Retrieved from Sole24ore: https://lab24.ilsole24ore.com/coronavirus/

Page $15 / 22$ 
25. Rusciano, V., Scarpato, D., \& Civero, G. (2019). TERRITORIALSOCIAL RESPONSIBILITY: A CLUSTER ANALYSIS ON A CASE STUDY. Calitatea, 20(S2), 543-548.

26. Moulaert, F. (2013). The international handbook on social innovation: collective action, social learning and transdisciplinary research. Edward Elgar Publishing, pp. 1-500.

27. Sadik-Zada E. R., \& Gatto, A. (2022). Vulnerability to urban heat islands effect in the global north and global south: a perspective on the drivers and mitigation strategies. Global Urban Heat Island Mitigation. Elsevier.

28. Gatto, A. (2020). A pluralistic approach to economic and business sustainability: A critical meta-synthesis of foundations, metrics, and evidence of human and local development. Corporate Social Responsibility and Environmental Management, 27(4), 1525-1539.

29. Gatto, A., \& Drago, C. (2021). When renewable energy, empowerment, and entrepreneurship connect: Measuring energy policy effectiveness in 230 countries. Energy Research \& Social Science, 78, 101977.

30. Colding, J., Barthel, S., Bendt, P., Snep, R., Van der Knaap, W., \& Ernstson, H. (2013). Urban green commons: Insights on urban common property systems. Global Environmental Change, 23(5), 1039-1051.

31. Colding, J., \& Barthel, S. (2013). The potential of 'Urban Green Commons' in the resilience building of cities. Ecological economics, 86, 156-166.

32. Buijs, A. E., Mattijssen, T. J., Van der Jagt, A. P., Ambrose-Oji, B., Andersson, E., Elands, B. H., \& Møller, M. S. (2016). Active citizenship for urban green infrastructure: fostering the diversity and dynamics of citizen contributions through mosaic governance. Current Opinion in Environmental Sustainability, 22, 1-6.

33. Zhang, J., Kang, L., Li, H., Ballesteros-Pérez, P., Skitmore, M., \& Zuo, J. (2020). The impact of environmental regulations on urban Green innovation efficiency: The case of Xi'an. Sustainable Cities and Society, 57, 102123.34.

34. Agovino, M., Cerciello, M., \& Gatto, A. (2018). Policy efficiency in the field of food sustainability. The adjusted food agriculture and nutrition index. Journal of environmental management, 218, 220-233.35.

35. Spagnoli, L., \& Mundula, L. (2021). Between Urban and Rural: Is Agricultural Parks a Governance Tool for Developing Tourism in the Periurban Areas? Reflections on Two Italian Cases. Sustainability, 13(14), 8108.

36. Lohrberg, F., Lička, L., Scazzosi, L., \& Timpe, A. (Eds.). (2016). Urban agriculture europe. Jovis.

37. Gatto, M., Bertuzzo, E., Mari, L., Miccoli, S., Carraro, L., Casagrandi, R., \& Rinaldo, A. (2020). Spread and dynamics of the COVID-19 epidemic in Italy: Effects of emergency containment measures. Proceedings of the National Academy of Sciences, 117(19), 10484-10491.

38. Cobianchi, L., Dal Mas, F., Peloso, A., Pugliese, L., Massaro, M., Bagnoli, C., \& Angelos, P. (2020). Planning the full recovery phase: an antifragile perspective on surgery after COVID-19. Annals of Surgery, 272(6), e296.

39. Ho, Y. S., \& Gatto, A. (2020). A Bibliometric Analysis of COVID-19 Research.

https://www.preprints.org/manuscript/202012.0624/v1

40. Gatto, A., Drago, C., \& Ruggeri, M. (2020). On the frontline-Sustainability and development research amidst the COVID-19 pandemic. https://assets.researchsquare.com/files/rs-103974/v1/ebe43fe5-3ffe-49aa-814a03460477db02.pdf?c=1631861680

41. Torzilli, G., Viganò, L., Galvanin, J., Castoro, C., Quagliuolo, V., Spinelli, A., ... \& Montorsi, M. (2020). A snapshot of elective oncological surgery in Italy during COVID-19 emergency: pearls, pitfalls, and perspectives. Annals of surgery, 272(2), e112. 
42. Romani, G., Dal Mas, F., Massaro, M., Cobianchi, L., Modenese, M., Barcellini, A., ... \& Ferrara, M. (2021). Population health strategies to support hospital and intensive care unit resiliency during the COVID-19 pandemic: The Italian experience. Population Health Management, 24(2), 174-181.43.

43. Gatto, A. \& Sadik-Zada, E. R. (2021), Governance matters. Fieldwork analysis of participatory budgeting, voting, and development from Campania, Italy. Journal of Public Affairs. DOI: 10.1002/pa.2769

44. Van den Berg, A. E., Maas, J., Verheij, R. A., \& Groenewegen, P. P. (2010). Green space as a buffer between stressful life events and health. Social science \& medicine, 70(8), 1203-1210.

45. Zijlema, W. L., Triguero-Mas, M., Smith, G., Cirach, M., Martinez, D., Dadvand, P., ... \& Julvez, J. (2017). The relationship between natural outdoor environments and cognitive functioning and its mediators.

Environmental research, 155, 268-275.

46. Nath, T. K., Han, S. S. Z., \& Lechner, A. M. (2018). Urban green space and well-being in Kuala Lumpur, Malaysia. Urban Forestry \& Urban Greening, 36, 34-41.

47. Cattivelli V., (2020), Gli orti urbani a Milano: attuale situazione e prospettive di sviluppo, EyesReg, Vol.10, N.3, May 202.

48. Cattivelli, V., (2021) Planning peri-urban areas at regional level: The case of Lombardy and Emilia-Romagna. Land use policy, Volume 103, April 2021, 105282 (IF 5.398).

49. Consolazio, D., Murtas, R., Tunesi, S., Gervasi, F., Benassi, D., \& Russo, A. G. (2021). Assessing the Impact of Individual Characteristics and Neighborhood Socioeconomic Status During the COVID-19 Pandemic in the Provinces of Milan and Lodi. International Journal of Health Services, 0020731421994842.

50. Rusciano, V., Civero, G., \& Scarpato, D. (2017). Urban gardening as a new frontier of wellness: Case studies from the city of Naples. Int. J. Sustain. Econ. Soc. Cult. Context, 13, 39-49.

51. Rusciano, V., Civero, G., \& Scarpato, D. (2017). URBAN GARDENS AND ENVIRONMENTAL SUSTAINABILITY: AN EMPIRICAL RESEARCH OF CAMPANIA REGION. Quality-Access to Success, 18.

52. Boccia, F., Covino, D., Sarno, V., \& Malgeri Manzo, R. (2017). The Role of Typical Local Products in the International Competitive Scenario. Quality-Access to Success, 18(160).

53. Rusciano, V., Civero, G., \& Scarpato, D. (2020). Social and ecological high influential factors in community gardens innovation: An empirical survey in Italy. Sustainability, 12(11), 4651.

54. Drago, C., Gatto, A., Ruggeri, M. (2021). Telemedicine as technoinnovation to tackle COVID-19: A bibliometric analysis. Technovation. https://doi.org/10.1016/j.technovation.2021.102417

\section{Figures}




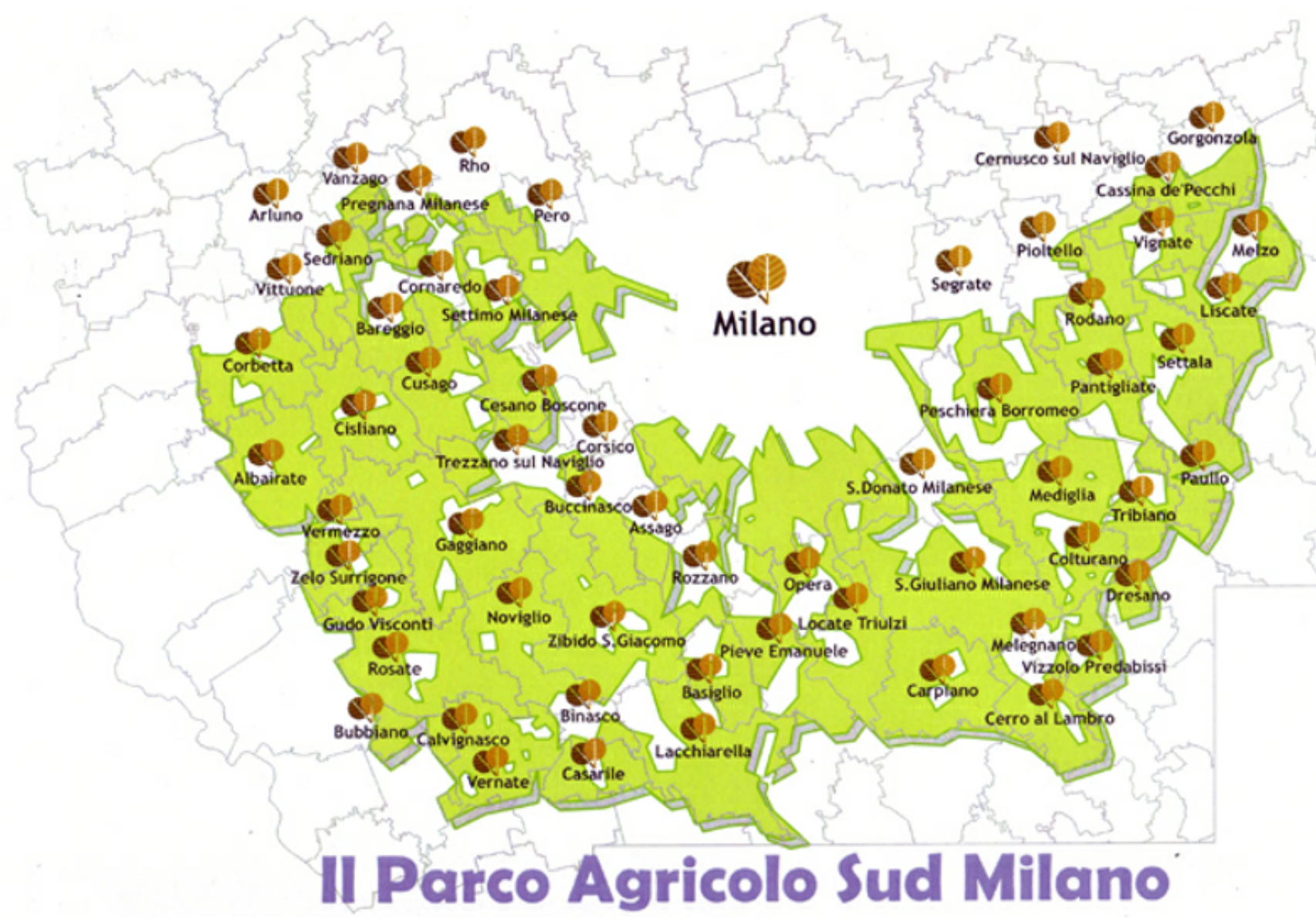

Figure 1

Parco Agricolo Sud Milano map, Source: website [15]

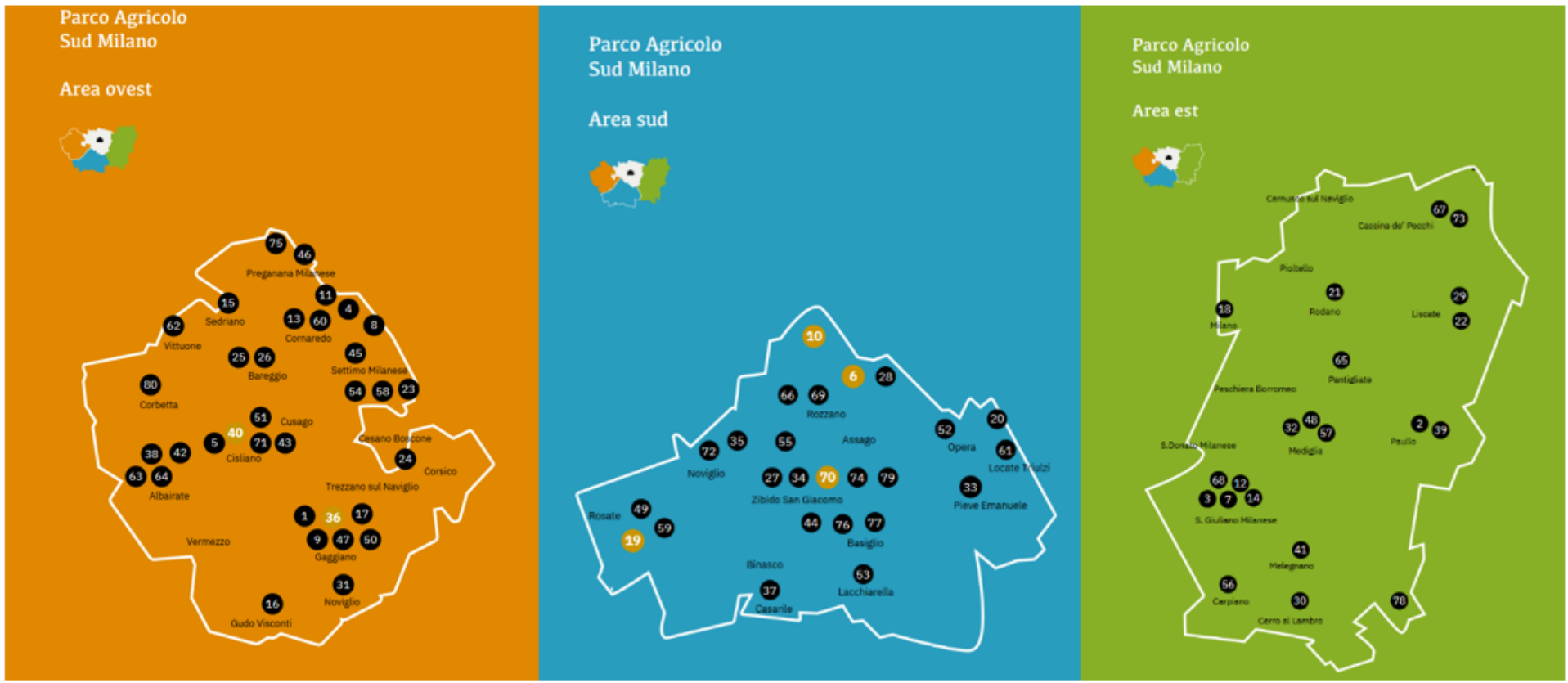

Figure 2 
Map of 79 networked farms in the Parco Agricolo Sud Milano. Source: website Città metropolitana Milano, 2017 [16]

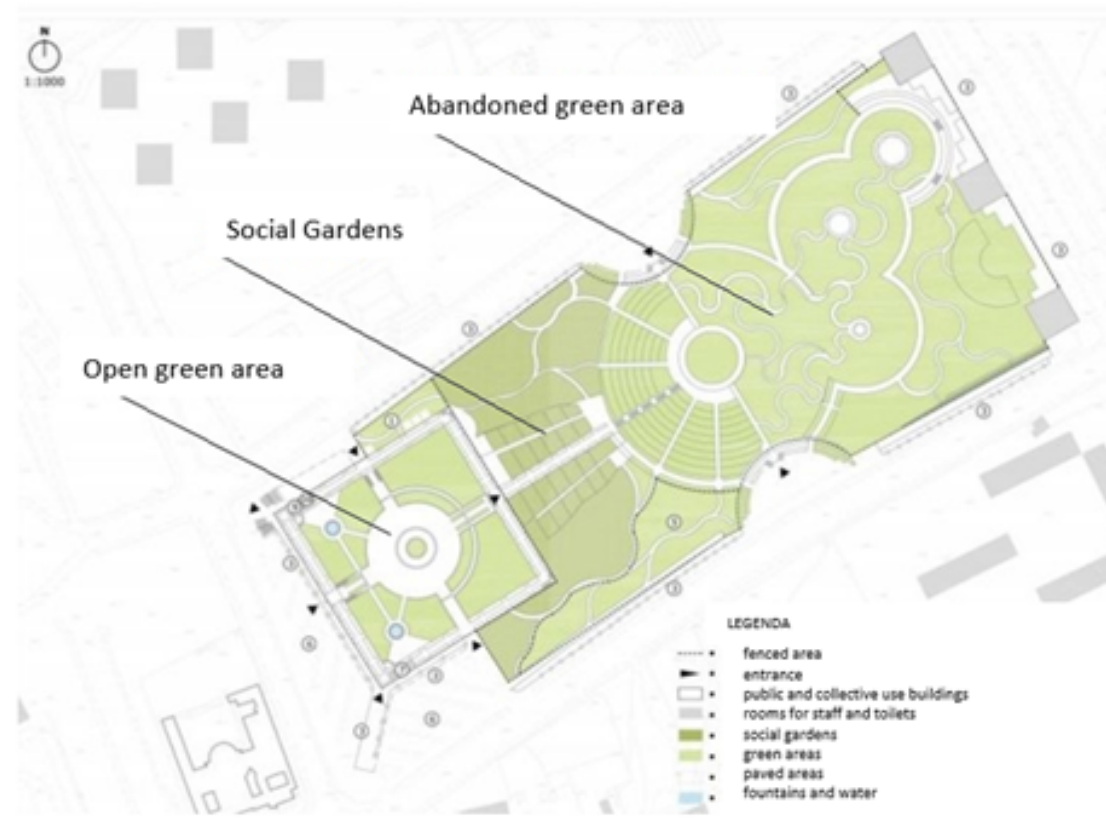

Figure 3

De Filippo Park map. Source: WWF Facebook page, 2020 [17]
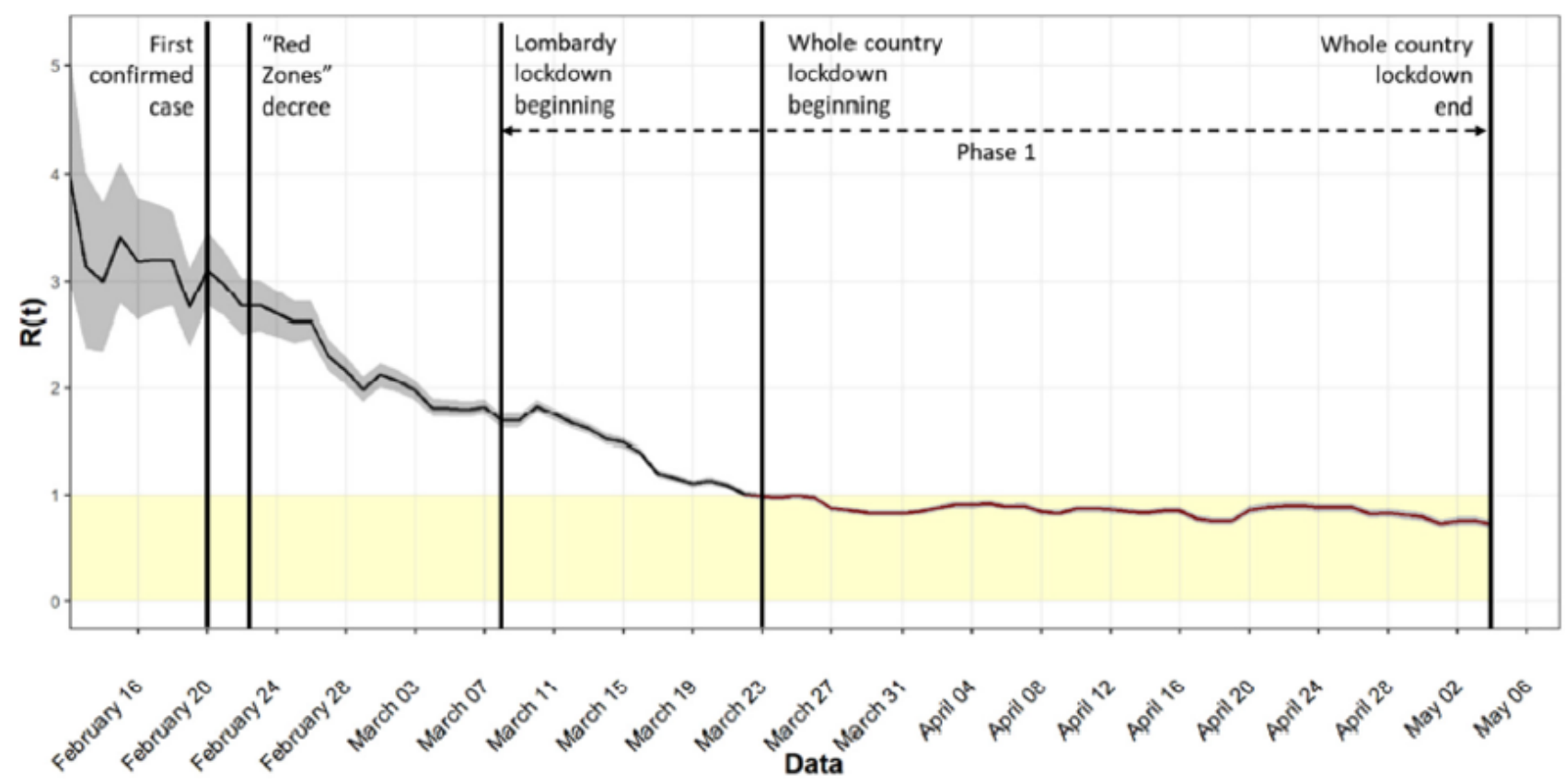

Institutional decrees and evolution of the effective reproduction number $\left(R_{t}\right) . R_{t}$ values below I indicate that the epidemic is slowing down (each patient infects, on average, less than I person). $R_{t}$ values above I indicate that the epidemic is progressing (each patient infects, on average, more than I person).

\section{Figure 4}


Source: Consolazio et al., 2021 [49].

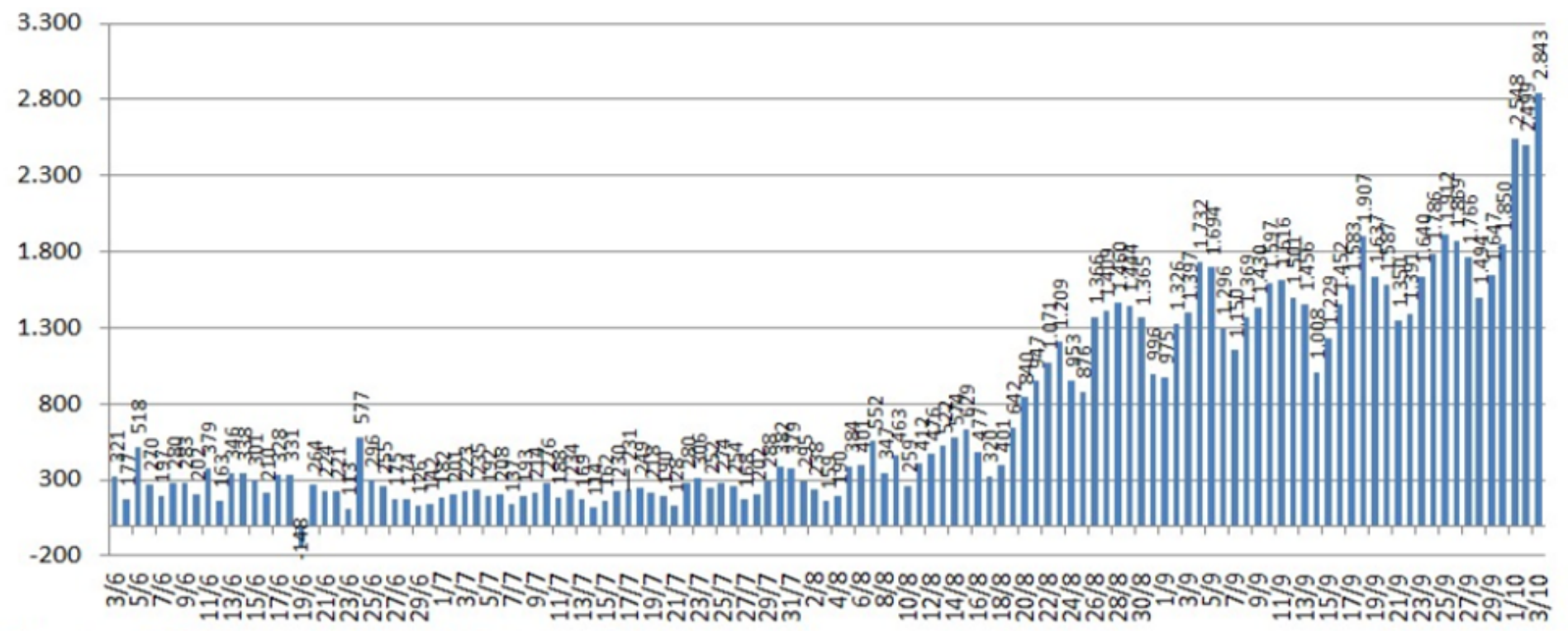

Figure 5

Italy- number of people infected by COVID-19 (SARS-CoV-2) per day. Source GIMBE, 2020 [23]
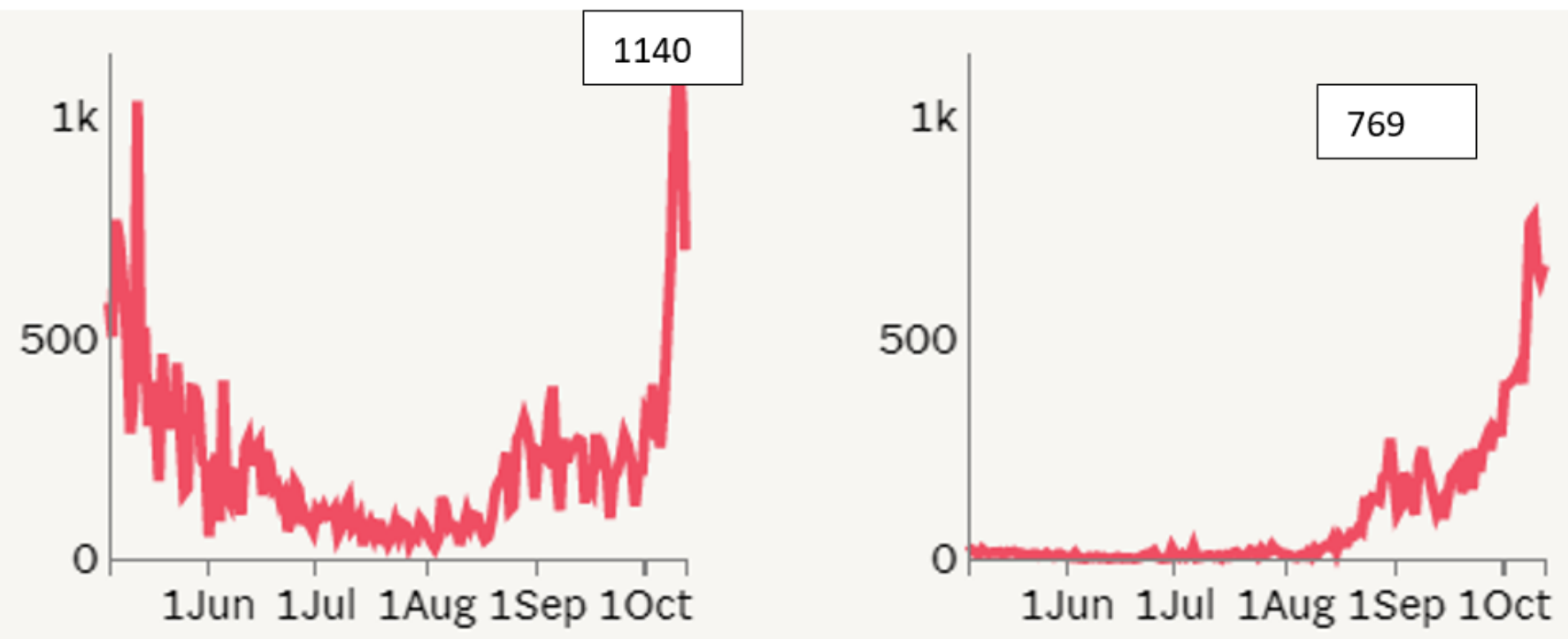

Figure 6

Trend of infections by COVID-19 (SARS-CoV-2) in Lombardy (left) and Campania (right). Source Sole 24 ore, 2020 


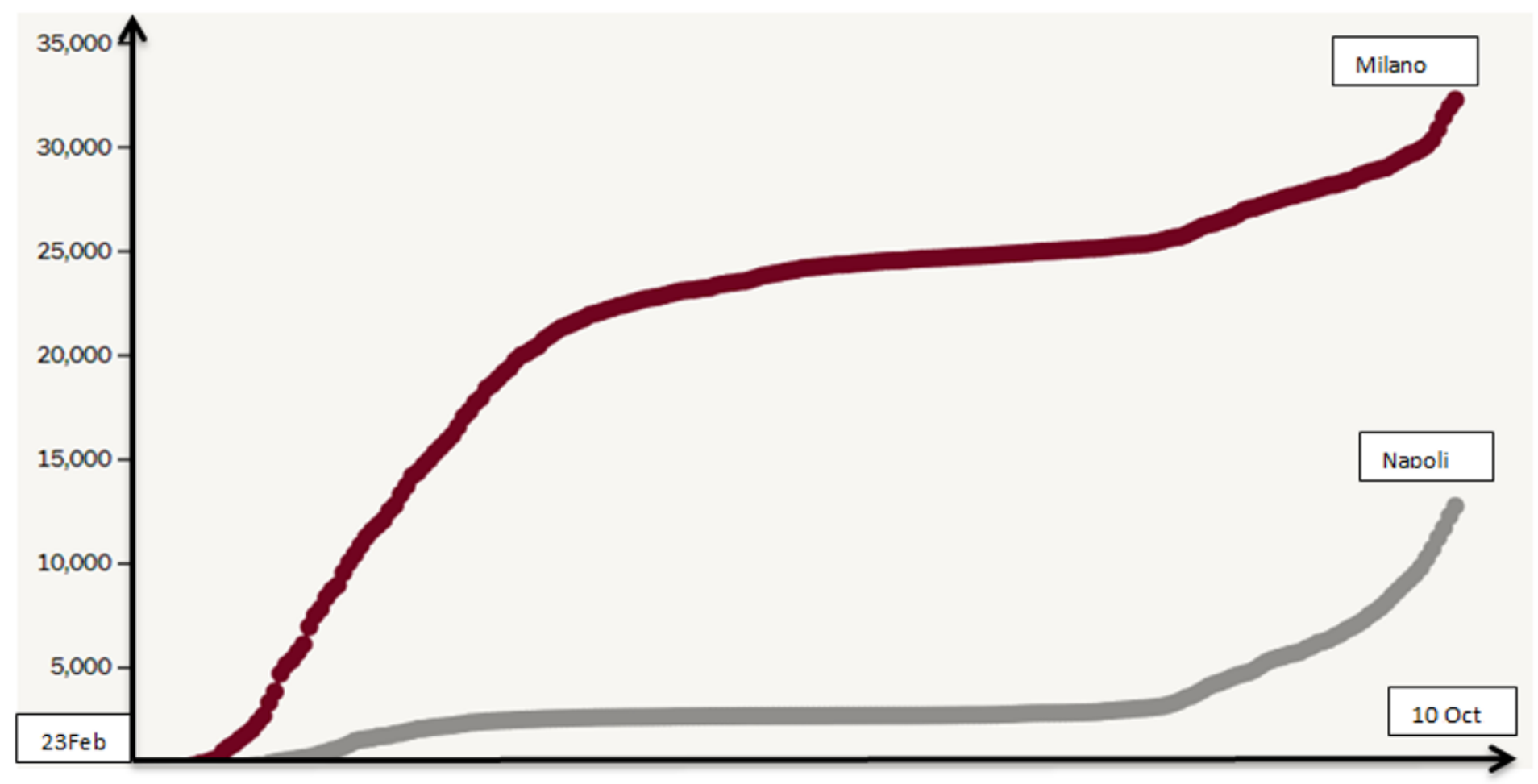

Figure 7

Trend of COVID-19 (SARS-CoV-2) infections in Milan and Naples. Source Sole 24 ore, 2020 [24]

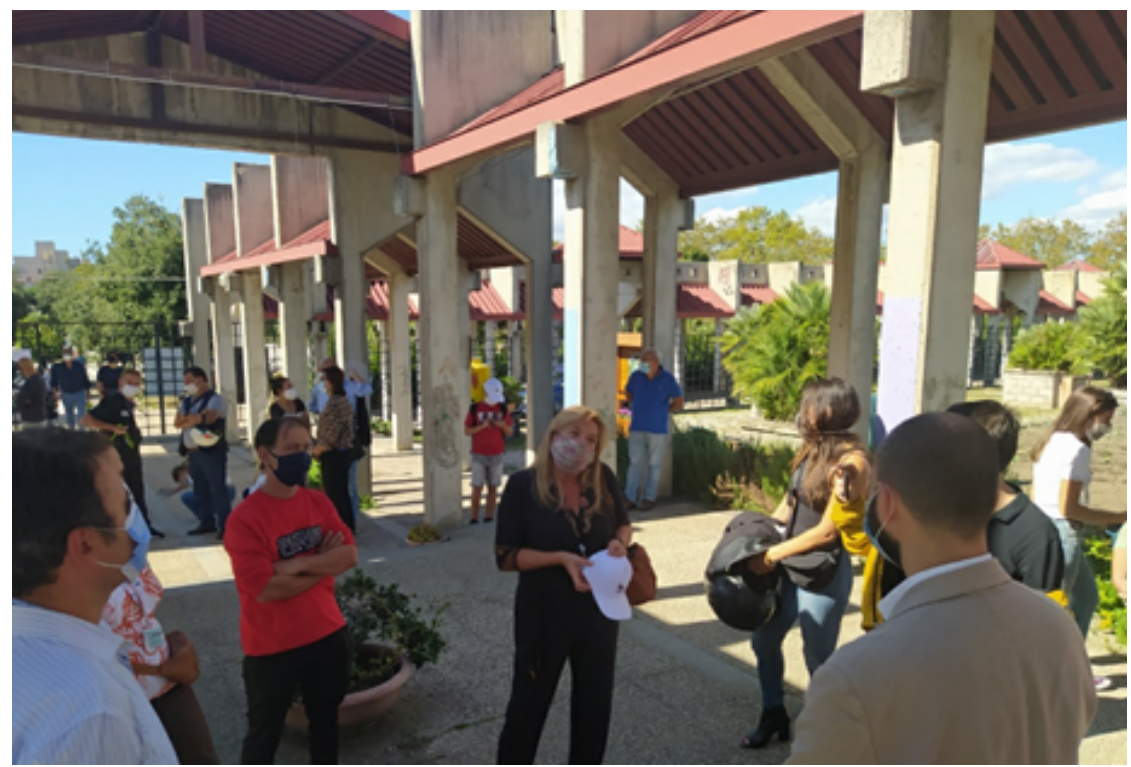

Figure 8

multi-stakeholder event in De Filippo park, October 3, 2020 - attended by urban green council member of Naples municipality, WWF Naples representatives and Lilliput managers (source: authors' elaboration).

\section{Supplementary Files}


This is a list of supplementary files associated with this preprint. Click to download.

- highlights.docx 